\title{
LOGIKA A PRAWOZNAWSTWO - UWAGI DOTYCZĄCE KSIĄŻKI TOMASZA BEKRYCHTA, MILENY KORYCKIEJ-ZIRK, KAROLA DOBRZENIECKIEGO, LOGICZNE ZAGADNIENIA PRAWOZNAWSTWA, WYD. 1, TOWARZYSTWO NAUKOWE ORGANIZACJI I KIEROWNICTWA, TORUŃ 2014, S. 196
}

Istnieje wiele publikacji, których celem jest ustalenie relacji zachodzących pomiędzy szeroko rozumianym prawoznawstwem a logiką w sensie ogólnym $^{1}$. Zdaniem samych autorów wyróżnikiem recenzowanej pozycji jest jej wielostronny charakter (czy wieloaspektowy? - oto jest pytanie... - s. 7), który przejawia się w prezentacji zagadnień będących faktycznym przedmiotem zainteresowania teoretyków prawa, prawników praktyków i studentów prawa związanych z zakresem badań logiki ogólnej, wydobyciu i uporządkowaniu wiedzy

* dr Piotr Sobol-Kołodziejczyk, adiunkt w Państwowej Wyższej Szkole Techniczno-Ekonomicznej w Jarosławiu

** dr Marek Zielinski, LL.M., adiunkt w Wyższej Szkole Handlowej w Kielcach

1 Zob. w szczególności: M. Klinowski, Logiczna problematyka czynu i sprawstwa, Wydawnictwo Uniwerystetu Jagiellońskiego, Kraków 2011, s. 168; J. Stelmach, B. Brożek, Sztuka negocjacji prawniczych, Wolters Kluwer, Warszawa 2011, s. 176; T. Widła, D. Zienkiewicz, Logika, wyd. 3, Beck, Warszawa 2011, s. 265; J. Nowak-Michalska, Modalność deontyczna w języku prawnym na przykładzie polskiego i hiszpańskiego kodeksu cywilnego, Wydawnictwo Rys, Poznań 2012, s. 279; K. Dobrzeniecki, M. Korycka-Zirk, Logika dla prawników. Kompendium, TNOIK, Touń 2013, s. 147; Prawo, język, logika. Księga jubileuszowa profesora Andrzeja Malinowskiego, red. S. Lewandowski, H. Machińska, J. Petzel, LexisNexis, Warszawa 2013, s. 324; W. Gromski, P. Jabłoński, J. Kaczor, M. Paździora, M. Pichlak, Warsztaty prawnicze. Logika praktyczna z elementami argumentacji prawniczej, Od.Nowa, Bielsko-Biała 2015, s. 212; S. Lewandowski, Retoryczne i logiczne podstawy argumentacji prawniczej, wyd. 2, Wolters Kluwer, Warszawa 2015, s. 276. 
z obszaru tej gałęzi logiki oraz oddaniu doniosłości analiz logicznych w rozumowaniach prawniczych.

Przed podjęciem właściwych uwag recenzyjnych dotyczących poszczególnych rozdziałów pracy należy odnotować, że już ustalenia definicyjne proponowane przez autorów we wstępie (s. 10-12) mogą budzić poważne wątpliwości metodologiczne. I tak, trudno uznać, że logika jest nauką humanistyczną², skoro jeden z jej podstawowych działów, czyli logika formalna, jest zazwyczaj wyrażana w postaci rachunków sformalizowanych bliskich notacji matematycznej i procedurom dowodzenia charakterystycznym dla tej ostatniej. Podobnie nie da się obronić poglądu, jakoby nauką humanistyczną było prawo. Nie wiedzieć dlaczego, autorzy wyróżniając trzy podstawowe działy logiki (semiotykę, logikę formalną i teorię nauki - s. 10), jednocześnie nie dokonali jej podziału na logikę sensu stricto i logikę sensu largo ${ }^{3}$. Ponadto nieprecyzyjny jest podział semiotyki logicznej, logiki formalnej i teorii nauki, ponieważ został on skonstruowany poprzez arbitralne wyliczenie (s. 11).

Omawiając elementy semiotyki logicznej (s. 15-94), autorzy wychodzą od klasycznego rozumienia tego pojęcia. Jednak z faktu, że recenzowana książka jest prawdopodobnie (sic!) ${ }^{4}$ podręcznikiem wynika, że określenie semiotyki zawiera błąd definicyjny ignotum per ignotum. Dzieje się tak dlatego, że w strukturze tej definicji wprowadzone jest pojęcie ,znaku”, które uprzednio nie zostało wyjaśnione. Podobna sytuacja ma miejsce w przypadku odwoływania się do następujących pojęć: ,język sztuczny”, „teoria odniesienia”, „teoria znaczenia” i „nazwa” (s. 18-23). Nadzwyczaj myląca jest przy tym strategia definiowania pojęcia „znaczenia” w odwołaniu się do terminu ,intencjonalność” (s. 19), który w tradycji filozoficznej był rozumiany w różny sposób ${ }^{5}$.

Dokonując szczegółowego omówienia elementów syntaktyki logicznej i semantyki logicznej, autorzy wychodzą od prezentacji kategorii składniowych (s. 23-28), co należy uznać za poprawne. Natomiast, już co do samego sposobu omówienia treści można mieć uzasadnione zastrzeżenia. Nie można przecież zde-

$2 \mathrm{Na}$ ten temat prowadzone są oczywiście ożywione dyskusje. Zob. Filozofia logiki, red. J. Woleński, Wyd. SPACJA - Fundacja Aletheia, Warszawa 1997, s. 10-11, 30, 80-90.

3 Szerzej o tym np. Mała encyklopedia logiki, red. W. Marciszewski, wyd. 2, Zakład Narodowy im. Ossolińskich, Wrocław 1988, s. 126.

4 Jest tak dlatego, że autorzy w żadnym miejscu wyraźnie tego nie sygnalizują.

5 Tak można to widzieć, dzięki opracowaniom, np. Z. Muszyński, J. Paśniczek, Wprowadzenie, w: Intencjonalność jako kategoria umystu i filozofi języka, red. tychże, Wydawnictwo UMCS, Lublin 2004, s. 7-8. 
finiować pojęcia „funktora” (s. 25) bez uprzedniego określenia, czym są „nazwy” i „zdania”. A tak właśnie czynią autorzy, co powoduje wrażenie zaburzenia porządku wykładu. Ze względu na to, że książka jest przeznaczona dla prawników, zdziwienie budzi fakt, iż w przypadku podziału nazw nie są w zasadzie podawane przykłady z zakresu szeroko rozumianego prawa (s. 28-37). Zarzutu tego nie można odnieść do fragmentów poświęconych zagadnieniu definiowania (s. 46-58). Na podkreślenie zasługuje również omówienie zasad definiowania w technice prawodawczej (s. 55-58). Niestety, omawiając kwestię błędów w definiowaniu, autorzy nie ustrzegli się rażących pomyłek, ponieważ pleonazm i przenośnia (s. 61) nie są błędami w definiowaniu. Traktuje się je raczej jako błędy logiczno-językowe ${ }^{6}$. $Z$ kolei podjęcie problematyki z zakresu pragmatyki logicznej jest narażone na zarzut arbitralności ${ }^{7}$. Podnosząc zagadnienie aktów mowy, autorzy omawiają wprawdzie koncepcję Johna L. Austina ${ }^{8}$ (s. 73-74), lecz zupełnie nic nie mówią na temat tej proponowanej przez Johna R. Searle'a ${ }^{9}$. Ta ostatnia stanowi twórcze i o wiele bardziej pełne rozwinięcie poglądów tego pierwszego autora ${ }^{10}$. Wątpliwości budzi również podział roli wypowiedzi na ekspresywne i ocenne (s. 77-78). Autorzy zdają się nie zauważać, że rola wypowiedzi jest pochodną funkcji języka. W tej perspektywie należałoby więc wprowadzić również impresywną rolę wypowiedzi, czego autorzy nie czynią. Wypada także stwierdzić, że nadzwyczaj myląca jest taktyka definiowania pojęć „kontekstu” i „intencji” w odwołaniu się do procedury indeksowania i kategorii światów możliwych (s. 92). Zagadnienia te są nadzwyczaj trudne i wymagają co najmniej dobrej znajomości formalnego systemu semantyki intensjonalnej. Tymczasem nie dość, że pojęcie „świata możliwego" autorzy ujmują w sposób nadzwyczaj swobodny (s. 92), to dodatkowo zupełnie nie wyjaśniają, w jaki sposób w procedurze indeksowania tworzy się kontekst wypowiedzi dla światów budowanych przez superpozycję.

6 Szerzej np. T. Kwiatkowski, Logika ogólna, Wydawnictwo UMCS, Lublin 1998, s. 152-155.

7 Jest właśnie tak dlatego, że autorzy dokonują nadzwyczaj swobodnego wyboru analizowanych przez siebie koncepcji.

8 Szerzej J.L. Austin, Mówienie i poznawanie: rozprawy i wykłady filozoficzne, Wydawnictwo Naukowe PWN, Warszawa 1993, s. 311-334.

9 J.R. Searle, Czynności mowy: ozważania z filozofii języka, Instytut Wydawniczy „Pax”, Warszawa 1987.

10 Więcej na ten temat P. Sobol-Kołodziejczyk, Johna Searle'a teoria intencjonalności, w: Intencjonalność..., s. 203 i n. 
Prezentacja zagadnień z zakresu logiki formalnej (s. 97-153) jest typowa. Jednak i w tej części książki autorzy nie uniknęli nieścisłości. Po pierwsze, logika formalna nie zajmuje się wyłącznie problematyką poprawnych wnioskowań ${ }^{11}$. Po drugie, definiując pojęcie ,wnioskowania” autorzy dokonali pomieszania perspektywy formalnej i perspektywy psychologicznej, twierdząc że wnioskowanie jest procesem intelektualnym (s. 97). Po trzecie, proces wnioskowania nie polega na wyprowadzaniu treści danego zdania z treści innego zdania (s. 97) ${ }^{12}$; jest to raczej proces uznawania prawdziwości danego zdania na podstawie prawdziwości zdań uznanych uprzednio. Po czwarte, równie nieprecyzyjnie ustalony jest zakres obowiązywania pojęcia „wnioskowań zawodnych”, gdyż autorzy zdali się zapomnieć, że prócz indukcji i analogii (s. 132-138) do zbioru wnioskowań zawodnych należy również procedura abdukcji ${ }^{13}$.

Wykład dotyczący klasycznego rachunku zdań (s. 99-109) jest poprawny. Autorzy mają rację, że klasyczny rachunek zdań jest najprostszym systemem logiki formalnej (s. 99). Nie dodają oni jednak - co jest nadzwyczaj istotne, że najważniejszą zaletą tego systemu jest jego pełność. Nie można mieć zastrzeżeń co do sposobu formalnej prezentacji podstawowych własności spójników ekstensjonalnych w postaci matryc prawdziwościowych (s. 100-107). Można co najwyżej dodać (czego autorzy nie czynią), że matryca negacji jest tabelą dla zleksykalizowanej negacji przyzdaniowej (s. 102). Natomiast matryca implikacji dotyczy wyłącznie implikacji materialnej (s. 104). Nie jest przy tym jasne, dlaczego autorzy spójnik implikacji traktują tak, jak gdyby był on tylko jeden ${ }^{14}$ (s. 104). Przecież powszechnie wiadomo, że na gruncie klasycznego rachunku zdań występują dokładnie cztery typy implikacji: prosta, odwrotna, przeciwna i przeciwstawna. Ma to szczególne znaczenie dla teorii prawa, jeśli zważy się na np. treść zdania: ,Jeśli popełniłem zabójstwo, to poniosę zasłużoną karę”. Zakładając, że jest to implikacja prosta i jest ona zarazem prawdziwa, to implikacja odwrotna: „Jeśli poniosę zasłużoną karę, to popełniłem zabójstwo”, prawdziwa być nie musi (ponieważ zasłużoną karę mogę ponieść także np. za kradzież lub pobicie). Tej konsekwencji i jej podobnych autorzy zdają się w ogóle nie zauwa-

11 Wbrew temu, co twierdzą autorzy na s. 97.

12 J. MacNamara, Logika i psychologia: rozważania z pogranicza nauk, Wydawnictwo Naukowe PWN, Warszawa 1993, s. 15-81.

13 Por. np. M. Urbański, Rozumowania abdukcyjne. Modele i procedury, Wydawnictwo Naukowe UAM, Poznań 2009, s. 161.

$14 \mathrm{Tj}$. wyłącznie implikacja prosta. 
żać. Na pochwałę zasługuje natomiast wyjaśnienie metod badania tautologiczności funkcji logicznych za pomocą metody sprawdzania zero-jedynkowego i metody dowodzenia nie wprost (s. 106-109).

Sposób prezentacji treści z zakresu rachunku nazw jest wybiórczy i niejasny (s. 109-116). Autorzy trafnie identyfikują, że klasyczny rachunek nazw jest tożsamy z sylogistyką Arystotelesa (s. 110). Podobnie słusznie twierdzą oni, iż fundamentem rachunku nazw są zdania kategoryczne (s. 110). Nieznane są jednak powody, dla których autorzy nie dokonują wprost podziału tych zdań na: ogólnotwierdzące, ogólnoprzeczące, szczegółowo twierdzące i szczegółowo przeczące ${ }^{15}$, wskazując jedynie, że zdania twierdzące różnią się od zdań przeczących jakością, zaś zdania ogólne różnią się od zdań szczegółowych ilością (s. 111). Wprowadza to - jak się wydaje - niepotrzebny zamęt pojęciowy. Zarzutu tego nie można odnieść do sposobu omówienia wnioskowań pośrednich i bezpośrednich na gruncie zdań kategorycznych (s. 114-116). Szkoda tylko, że autorzy nie pokusili się o wskazanie tzw. sylogizmów niezawodnych (np. BaRBaRa, CeLaReNT, DaRii) z wykorzystaniem zdań kategorycznych należących do języka prawnego i języka prawniczego.

W odniesieniu do podstawowych problemów prawoznawstwa omówienie języka klasycznego rachunków predykatów w postaci proponowanej przez autorów (s. 116-125) wymaga kilku uwag krytycznych. Oczywiście syntaktyka tego rachunku została zrekonstruowana w sposób poprawny (s. 120-127). Sposób odczytywania formuł rachunku kwantyfikatorów jest przedstawiony o tyle ciekawie, że obejmuje faktyczne zdania zawarte chociażby w języku prawnym (np. sformalizowaną analizę art. 148 Kodeksu karnego ${ }^{16}$ - s. 121). Jednak w tej części recenzowanej książki autorzy właściwie nie przedstawiają metod badania prawdziwości formuł na gruncie rachunku kwantyfikatorów, twierdząc jedynie, że identyfikowanie prawdziwości nie jest proste (s. 125). W kontekście tej uwagi można się raczej domyśleć, niż wyraźnie to odczytać, iż zdaniem autorów podstawowym rodzajem wynikania w ramach omawianego rachunku jest wynikanie semantyczne (s. 125-129). Tak jest w istocie, jednak wiążąc pojęcie „wynikania semantycznego" z pojęciem „modelu”, autorzy nie podają znaczenia tego ostatniego terminu (s. 125). Nie wskazują również, w jaki sposób konstruuje się model i w jaki sposób w danym języku treść modelu wzbogaca się o wartość logiczną

15 J. Łukasiewicz, Sylogistyka Arystotelesa z punktu widzenia współczesnej logiki formalnej, PWN, Warszawa 1988, s. 12-17.

16 Ustawa z dnia 6 czerwca 1997 r. - Kodeks karny. Dz.U. z 1997 r., nr 88, poz. 553 z późn. zm. 
(s. 128). A przecież zagadnienia te są powszechnie znane i mają ugruntowaną tradycję głównie za sprawą badań prowadzonych przez logików polskich ${ }^{17}$.

Odnosząc się do kwestii wnioskowań niededukcyjnych (s. 132-143), autorzy poprawnie omawiają schematy indukcji prostej i indukcji eliminacyjnej. Warto by jednak było dodać i wskazać przykłady, w których stosowanie mechanizmów indukcji prostej prowadzi do paradoksów. Byłoby również pożądane podanie chociaż jednego przykładu zastosowania metody indukcji eliminacyjnej, czego nie ma miejsca w recenzowanej książce. Taki sam postulat można zgłosić co do kwestii omówienia podstawowych rodzajów wnioskowań prawniczych (s. 138-143).

Mówiąc o teoriach argumentacji prawniczej (s. 155-172), autorzy wskazują, że teorie te jawnie nawiązują do tradycji starożytnych szkół filozoficznych (s. 155). Z dużą swobodą określają oni jednak zasięg stosowania pojęcia ,argumentacji" (s. 156-157), co może wywoływać zdziwienie, gdyż w odniesieniu do tej problematyki istnieje wiele dobrych wzorców ${ }^{18}$, z których warto korzystać. Uwaga ta nie jest przypadkowa, jeśli zważy się na istnienie wielu rodzajów argumentów, np. argumenty proste, argumenty złożone, argumenty szeregowe $\mathrm{i}$ argumenty wspierające ${ }^{19}$, co w procesie argumentowania ma podstawowe znaczenie. $Z$ punktu widzenia celów postawionych we wstępie recenzowanej książki nie są również jasne powody omówienia historycznego tła teorii argumentacji (s. 157-159). Podobnie w prezentacji podstawowych założeń modelu epistemiczno-technologicznego autorzy w sposób bardzo dyskusyjny konstruują związek niezależności tego modelu od norm moralnych z technologiczną koncepcją prawa (s. 162), gdyż na gruncie proponowanego wyjaśnienia należałoby wyraźnie stwierdzić, że model ten jest pochodną koncepcji semantyki warunków prawdziwościowych. Z kolei w przypadku omówienia modelu retoryczno-topicznego (s. 162-166) autorzy nie wskazują żadnych praktycznych sposobów jego zastosowania. Natomiast referat dotyczący modelu komunikacyjnego jest prostą prezentacją koncepcji sformułowanej przez Jürgena Habermasa ${ }^{20}$ niezawierającą choćby elementarnej próby rozwinięcia idei podjętej przez niemieckiego myśliciela.

17 Tytułem przykładu zob. A. Tarski, Pojęcie prawdy w językach nauk dedukcyjnych, wyd. 1, Towarzystwo Naukowe Warszawskie, Warszawa 1933.

18 Zob. np. M. Tokarz, Argumentacja, perswazja, manipulacja, wyd. 1, Gdańskie Wydawnictwo Psychologiczne, Gdańsk 2006, s. 123-154.

19 Szerzej np. tamże, s. 136-138.

20 Por. J. Habermas, Teoria działania komunikacyjnego, t. I, Racjonalność działania a racjonalność społeczna, Wydawnictwo Naukowe PWN, Warszawa 1999, s. 189. 
Rozważania dotyczące elementów teorii nauki (s. 173-190) stanowią najsłabszą partię recenzowanej książki. Wprawdzie, podejmując zagadnienie systematyzacji, autorzy poprawnie dokonują wyróżnienia operacji intelektualnych składających się na to pojęcie (s. 173-174), to jednak trzeba w tym miejscu wyraźnie podkreślić, że nie udało im się uniknąć błędów i niedopowiedzeń. Dotyczy to w szczególności zagadnienia klasyfikacji logicznej i podziału logicznego (s. 174-178). W ujęciu autorów klasyfikacja logiczna jest pierwotna względem podziału logicznego (s. 174-176), co okazuje się być jawnym fałszem. Pierwotny jest zawsze podział logiczny, gdyż jest on tylko jednostopniowy. Natomiast klasyfikacja logiczna jest po prostu rozbudowanym podziałem logicznym ${ }^{21}$. Ponadto autorzy nie wspominają, że podział logiczny zwykle przybiera postać dychotomiczną 22 . Podobnie rzecz ma się w przypadku omówienia zagadnienia prawdy (s. 179-183). O ile autorzy trafnie zauważają, że pojęcie „prawdy” sprawia niebagatelne kłopoty definicyjne (s. 179), o tyle z ustalenia tego nie wyprowadzają żadnych interesujących wniosków. W swoich rozważaniach wyróżniają oni jedynie rozróżnienia na klasyczne i nieklasyczne koncepcje prawdy (s. 180). W ostatnim przypadku dokonują oni arbitralnego wyliczenia sformułowanych w filozofii i logice koncepcji na ten temat (s. 181-183), jednak zapominają, że np. redundancyjna i deflacyjna koncepcja prawdy są również teoriami nieklasycznymi ${ }^{23}$. Dużym błędem jest z kolei stwierdzenie, że definicja „prawdy” dla języka naturalnego jest niemożliwa, ponieważ język ten jest semantycznie zamknięty (s. 183). Wprost przeciwnie - tylko języki sztuczne cechuje ta własność ${ }^{24}$. Nie sposób zrozumieć zatem tezy autorów, że język prawniczy cechuje jakiś logicznojęzykowy paradygmat (s. 187). Aby tak było, należałoby wykazać, że prawoznawstwo sensu stricto w szczególności, a prawo w ogólności, rozwija się zgodnie z wyznacznikami rozwoju nauki w sensie nadanym temu terminowi przez Thomasa S. Kuhna ${ }^{25}$.

21 Tak właśnie, np. W. Wolter, M. Lipczyńska, Elementy logiki. Wykład dla prawników, wyd. 3, PWN, Warszawa-Wrocław 1980, s. 54.

22 Por. np. tamże, s. 51.

${ }^{23}$ Zob. np. A. Grobler, Pomysty na temat prawdy i sposobu uprawiania filozofii w ogóle, Aureus, Kraków 2001, s. 164-165.

24 Szerzej np. P. Sobol-Kołodziejczyk, Is Ajdukiewicz's semantics procedural? The view from the Study of Artificial Intelligence, w: Język i poznanie. W 120. rocznicę urodzin Kazimierza Ajdukiewicza, red. W. Słomski, Wydawnictwo Wyższej Szkoły Finansów i Zarządzania w Warszawie, Warszawa 2010, s. 147-156.

25 Szerzej T.S. Kuhn, Struktura rewolucji naukowych, PWN, Warszawa 1968, s. 39-51. 
Podsumowując, zamierzeniem autorów było wskazanie na integracje, które zachodzą pomiędzy logiką a prawoznawstwem (s. 191). Podjętą przez nich próbę należy uznać za nieudaną. Wydaje się bowiem, że recenzowana książka stanowi dobitny przykład tego, jak trudno powiązać jest zagadnienia z zakresu logiki i prawoznawstwa. Jeszcze trudniej wskazać na praktyczne zastosowania logiki w prawoznawstwie i praktyce prawniczej. Nie znaczy to oczywiście, że zastosowania takie nie istnieją ${ }^{26}$.

Książka stanowi zatem typowy podręcznik akademicki - taki, jakich jest wiele na polskim rynku wydawniczym. Niewątpliwie zabrakło w niej omówienia problematyki błędów logicznojęzykowych, w szczególności błędów znaczeniowych i błędów naruszających zasadę ekonomii w formułowaniu myśli ${ }^{27}$. Można sądzić, że owe błędy są jednymi z najczęściej popełnianych tak w naukach prawnych, jak i w praktyce prawniczej. W odniesieniu do recenzowanej pozycji można również postawić zarzut, że przykłady zostały dobrane w sposób wyjątkowo nieadekwatny (np. s. 37). Rzadko dotyczą one bowiem problemów z zakresu szeroko rozumianego prawoznawstwa. Książka ta jest także niedopracowana pod względem edycyjnym. Zamieszczona bibliografia (s. 193-196) często nie znajduje odzwierciedlenia w przypisach. Nie zawarto również indeksu rzeczowego i spisu podstawowych symboli logicznych, które niewątpliwie ułatwiłyby lekturę recenzowanej książki i należą do pewnego standardu przyjętego dość powszechnie w nauce polskiej.

26 Dla przykładu można podjąć próbę (nawet w odwołaniu się do logiki klasycznej) wykorzystania rachunków logicznych w procedurze badania niesprzeczności aktów prawnych.

27 Zob. np. T. Kwiatkowski, Logika..., s. 152-155. 